\title{
Evaluation of cariogenic antibacterial activity of mineral trioxide aggregate and Portland cement
}

\author{
Avaliação da atividade antibacteriana do MTA e do Cimento Portland sob bactérias cariogênicas
}

\author{
Paulo Maurício Reis de MELO JÚNIOR ${ }^{1}$ \\ Ana Paula Veras SOBRAL ${ }^{1}$ \\ Gerhilde Callou SAMPAIO' \\ Isabel Maria de Araújo PINTO' \\ Neide Kazue Sakugawa SHINOHARA'
}

\section{ABSTRACT}

\section{Objective}

The objective of this study was to evaluate the antimicrobial activity of Mineral trioxide aggregate e Portland cement against some selected cariogenic bacteria.

\begin{abstract}
Methods
Wells were made of approximately $0.5 \mathrm{~mm}$ in diameter, in solid culture media and immediately filled with cement. Twelve samples of each material were obtained for the realization of the agar diffusion method. These samples were tested with Streptococcus mutans (ATCC 700610), Enterococcus faecalis (ATCC 29212), Lactobacillus acidophilus (UFV) and Lactobacillus casei (UNICAMP). Petri plates containing Tripticase soy Agar (TSA) were used for the growth of Streptococcus mutans and Enterococcus faecalis, and plates of Man Rogosa \& Sharpe Agar (MRS) for the Lactobacillus acidophilus and Lactobacillus casei. After 48 hours of incubation, it was made the measurement of inhibition halos with the aid of manual caliper.
\end{abstract}

Results

The diameters obtained to MTA $(2.50 \pm 0.00 ; 2,92 \pm 0.63 ; 2.58 \pm 0.38), P C(1.17 \pm 0.29 ; 2.00 \pm 0.43 ; 1.33 \pm 0.14)$ and calcium hydroxide cement $(3.83 \pm 0.29 ; 3.00 \pm 0.00 \pm 2.58 \pm 0.72)$ were expressed in millimeters and subsequently submitted to Tukey test $(p<0.05)$.

\section{Conclusion}

According to the results obtained, it was concluded that the MTA and Portland cement showed to have similar antimicrobial properties, however these were not effective against the Enterococcus faecalis.

Indexing terms: Bacteria. Dental cements. Products with antimicrobial action.

\section{RESUMO}

Objetivo

Avaliar a atividade antimicrobiana do MTA e do cimento Portland sobre bactérias cariogênicas.

\section{Métodos}

Poços foram confeccionados e imediatamente preenchidos com os materiais. Doze amostras de cada material foram obtidas para realização do método de difusão em Ágar. As amostras foram testadas com o Streptococcus mutans (ATCC 700610), Enterococcus faecalis (ATCC 29212), Lactobacillus acidophilus (UFV) and Lactobacillus casei (UNICAMP). Placas de petri contendo Ágar Tripticase de Soja (MERCK) foi utilizado para - Streptococcus mutans e o Enterococcus faecalis e o meio Ágar Man Rogosa \& Sharpe (MRS) para os o Lactobacillus acidophilus e Lactobacillus casei. Depois de 48 horas de incubação foram realizadas as medidas dos halos de inibição com o auxílio de um paquímetro manual.

\section{Resultados}

Os diâmetros obtidos do MTA $(2.50 \pm 0.00 ; 2,92 \pm 0.63 ; 2.58 \pm 0.38), C P(1.17 \pm 0.29 ; 2.00 \pm 0.43 ; 1.33 \pm 0.14)$ e cimento de hidróxido de cálcio $(3.83 \pm 0.29 ; 3.00 \pm 0.00 \pm 2.58 \pm 0.72)$ foram expressos em milímetros e submetidos ao teste de Tukey $(p<0.05)$.

\section{Conclusão}

De acordo com os resultados obtidos concluiu-se que o MTA e o cimento Portland demonstraram possuem propriedades antimicrobianas semelhantes, porém não foram efetivos contra o Enterococcus faecalis.

Termos de indexação: Bactéria. Cimentos dentários. Produtos com ação antimicrobiana.

\footnotetext{
${ }^{1}$ Universidade de Pernambuco, Faculdade de Odontologia, Departamento de Dentística Restauradora. Av. General Newton Cavalcanti, 1650, Vila da Fábrica, 54759-220, Camaragibe, PE, Brasil. Correspondência para / Correspondence to: PMR MELO JUNIOR. E-mail: <paulo.reis@upe.br>.
} 


\section{INTRODUCTION}

Dental caries is an infectious and contagious disease that represents the main risk factor to pulp and periapical tissues, causing the destruction of hard tooth tissues ${ }^{1}$.

The dental pulp presents anatomical and physiological conditions, which limit its response in the presence of infections and did not promote satisfactory healing, repair and cure of its tissue.

Deep cavities of caries configures as an accessible pathway to microorganisms to the pulp, and the pulpdentin protection material used on restorations of these teeth must have physical, chemical, antimicrobial and biological properties.

Calcium hydroxide $(\mathrm{CaOH})$ has been selected as a great material to several clinical procedures for its biocompatibility, mineralized tissue stimulation and the increased $\mathrm{pH}$, caused by the dissociation of calcium hydroxide into calcium and hydroxide ions, which is responsible for the observed antimicrobial activity, in which most of the microorganisms do not manage to survive ${ }^{2}$. However, physical and mechanical properties of this cement, such as solubility and resistance, have been subjects of doubts.

Current evidence in the literature has consistently demonstrated a better outcome when using MTA (mineral trioxide aggregate), material idealized in Loma Linda University (USA) to seal off suggested pathways of communication between the root canal system and the external surface of the tooth ${ }^{3}$. This cement is an aggregate composed by tricalcium silicate, dicalcium silicate, tricalcium aluminate tricalcium silicate, aluminum tetracalcium ferrite, and dehydrated calcium sulfate and bismute oxide. When used in pulp capping therapy it's observed the earlier formation of the odontoblastic layers, and also a light presence of hyperemia, inflammation or necrosis and the formation of dentinal bridges was more pronounced. Various aspects and properties of this material have been studied and its antimicrobial activity has revealed the growth inhibition of microorganisms of the oral cavity, justified by the high $\mathrm{pH}$ and because the calcium hydroxide is the main component released from the MTA in aqueous medium ${ }^{4}$.

The MTA and Portland cement has similarities in their chemical composition, physical properties, biocompatibility and tissue response ${ }^{5-9}$. Therefore, the aim of this study was to evaluate the antimicrobial activity of MTA e PC against some selected cariogenic bacteria.

\section{METHODS}

The tested materials were: MTA (Angelus Soluções Odontológicas, Londrina, Brasil), Portland cement (CP II F32, ITAPESSOCA AGRO-INDUSTRIAL S.A., Goiana, Brasil) and calcium hydroxide paste (Reagen TM).

The antimicrobial activity of the materials was evaluated by the Agar diffusion method against four different strains.

The strains used for analysis were Streptococcus mutans (ATCC 700610), Enterococcus faecalis (ATCC 29212), Lactobacillus acidophilus and Lactobacillus casei isolated by the Laboratory of Microbiologic Science (Federal University of Viçosa - MG (UFV) and University State of Campinas - UNICAMP, SP, Brazil), respectively.

Of each bacterial culture tested, it was held a concentration suspension of approximately $5 \times 108$ of colonies per $\mathrm{mL}$, corresponding to 0.5 of $\mathrm{Mc}$ Farland em range of sterile medium Trypticase Soy Browth (TSBMerck). The Streptococcus mutans and Enterococcus faecalis suspensions were inoculated with spread plate in the middle of Sodium Tioglicolate (Merck) culture and Lactobacillus and Lactobacillus acidophilus casei were inoculated in the culture medium Man Rogosa \& Sharpe Agar (MRS-HIMEDIA). Subsequently, the plates were incubated at $35 \pm 1^{\circ} \mathrm{C}$ for $24 / 48 \mathrm{~h}$ and the halos of inhibition were expressed in millimeters, using a caliper manual.

A total of 12 plates were employed, each microorganism was tested in triplicate. Three cavities, measuring $4 \mathrm{~mm}$ in diameter were made in each agar plate using a copper puncher and then completely filled with freshly manipulated product to be tested.

Positive $(\mathrm{CaOH})$ and negative controls (sterile growing medium) were tested using the same methodology and under the same conditions of the experiment.

All culture plates were incubated at $35 \pm 10 \mathrm{C}$ for 24/48h. The plates that had Streptococcus mutans were incubated on Gasparck jar with a generator of atmosphere of oxygen depletion (Anaerocult). The halos of microbial inhibition were measured by a ruler with millimeter scale, with precision scale of $0,5 \mathrm{~mm}$. The results were determined by the average and standard deviation. The arithmetic average of the four measurements of the end of samples up to the limit of the halos of inhibition of microbial activity was obtained and the average value of three repetitions performed for each culture tested was expressed in $\mathrm{mm}$. The data were statistically analyzed by Kruskal-Wallis test with a significance level of $5 \%$ to compare the differences 
between MTA, Portland cement (PC) and calcium hydroxide paste (CHP). All procedures were performed under aseptic conditions in laminar flow Chapel.

\section{RESULTS}

The results of antimicrobial effect of experimental products are shown in Table 1. Analysis of the efficacy of these materials against the microorganisms tested demonstrated that all microbial species used in the study had their growth inhibited. Nevertheless, MTA,
PC and CHP were incapable to inhibit the growth of $E$. faecalis.

The calcium hydroxide paste (Positive control) showed bigger inhibition halos against Streptococcus mutans, Lactobacillus acidophilus and Lactobacillus casei than both MTA and Portland cement. This difference was statistically significant only against Lactobacillus acidophilus $(p<0.05)$.

MTA showed more antimicrobial activity than PC, but not to a significant degree ( $p>0.05$ ). MTA and PC were more effective against Lactobacillus acidophilus and CHP against Streptococcus mutans.

Table 1. Means and standard deviation of inhibition haloes $(\mathrm{mm})$

\begin{tabular}{lcccc}
\hline Bacteria & \multicolumn{4}{c}{ Cements } \\
& MTA & CP & Ca $\left(\mathrm{OH}_{2}\right)$ & -value * \\
& Mean \pm SD & Mean \pm SD & Mean \pm SD & \\
\hline S. mutans & $2,50 \pm 0,00$ & $1,17 \pm 0,29$ & $3,83 \pm 0,29$ & 0,023 \\
L. acidophillus & $2,92 \pm 0,63$ & $2,00 \pm 0,43$ & $3,00 \pm 0,00$ & 0,088 \\
L. casei & $2,58 \pm 0,38$ & $1,33 \pm 0,14$ & $2,58 \pm 0,72$ & 0,059 \\
\hline
\end{tabular}

Note: $\left.{ }^{*}\right)$ Kruskal-Wallis test.

\section{DISCUSSION}

The agar diffusion method used in the present study is one of the most commonly employed techniques for evaluation of antimicrobial activity ${ }^{10-12}$.

The antimicrobial effect of MTA and PC measured the test of inhibition in agar was already observed against microorganisms ${ }^{13-15}$. However, no previous studies have evaluated the antimicrobial activity exclusively against bacterial strains of deep decayed dentin ${ }^{16-17}$.

Our results revealed that all the material tested have antimicrobial activity, substantiated by the formation of growth inhibition halos, however, no activity was found against Enterococcus faecalis, opportunist microorganism on cariogenic lesion and infect root canal.

Recently, in contrast of the results of our study, MTA did not exhibit antimicrobial activity against $S$. mutans, a Gram-positive, facultative anaerobic bacterium, commonly found in the human oral cavity and significant contributor to tooth decay ${ }^{18}$.

The antimicrobial activity of calcium hydroxide has been reported by the ability of ionization and releasing hydroxyl ions, raising the $\mathrm{pH}$ levels, creating an unfavorable environment for microbial growth ${ }^{19-20}$.
PC and MTA contain calcium oxide, which, when mixed with water, forms calcium hydroxide, which induces an increase of $\mathrm{pH}$ by dissociation of calcium and hydroxide ions $^{6,21-22}$

Torabinejad \& Parirokh ${ }^{23}$ observed an initial $\mathrm{pH}$ of 10.2 for MTA, rising to 12.5 in $3 \mathrm{~h}$. It is known that $\mathrm{pH}$ levels in the order of 12.0 can inhibit a bigger amount of microrganisms, including resistant bacteria such as Enterococcus faecalis.

However, in this study all materials were ineffective against E. faecalis, as similar to those observed in the literature related to Estrela et al. ${ }^{4}$, Ribeiro et al. ${ }^{13}$, Zarrabi et al. ${ }^{14}$ and Miyagak et al. ${ }^{24}$, in constrast to the results presented in Sipert et al. ${ }^{11}$ and Tanumaru Filho et al. ${ }^{12}$ investigations.

This variation of the results can be attributed to alkaline resistance or dilution of cements in aqueous environments of bacterial cultures, consequently decreasing the $\mathrm{pH}$ levels as reported by by Islam et al. ${ }^{25}$ and Vasconcelos et al. ${ }^{26}$ which confirmed this loss 3 hours after manipulation of the PC.

The present study revealed that the diameter of the inhibition zone varied according to the microorganism tested. The results obtained for Portland cement and MTA demonstrate that both materials have similar antimicrobial properties, besides the mineralization ability. The fact that 
main chemical components found in MTA are also present in Portland cement can justify why the results were similar. Both also had more pronounced antimicrobial effects against Lactobacillus acidophilus.

\section{CONCLUSION}

According to the methodology proposed, and based on the present results, it may be concluded that

\section{REFERENCES}

1. Orstavik FT. Endodontia: prevenção e tratamento da periodontite apical. São Paulo: Santos; 2004.

2. Holland R, De Souza V. Ability of a new calcium hydroxide root canal filling material to induce hard tissue formation. J Endod. 1985;11(12):535-43.

3. Lee SJ, Monsef M, Torabinejad M. Sealing ability of a mineral trioxide aggregate for repair of lateral root perforations. J Endod. 1993;19(11):541-4.

4. Estrela C, Bahmann LL, Estrela CR, Silva RS, Pécora JD. Antimicrobial and chemical study of MTA, Portland cement, calcium hydroxide paste, Sealapex and Dycal. Braz Dent J. 2000;11(1):3-9.

5. Torabinejad M, Parirokh M. Mineral Trioxide Aggregate: a comprehensive literature review - part I: chemical, physical, and antibacterial properties. J Endod. 2010;36(1):16-27. doi: 10.1016/j.joen.2009.09.006

6. Holland R, De Souza V, Nery MJ. Reaction of rat connective tissue to implanted dentin tube filled with mineral trioxide aggregate, Portland cement, or calcium hydroxide. Braz Dent J. 2001a;12(1):3-8.

7. Menezes R, Bramante CM, Letra A, Carvalh VG, Garcia RB. Histologic evaluationof pulpotomies in dog using two types of mineral trioxideaggregate and regular and white Portland cements aswound dressings. Oral Surg Oral Med Oral Pathol Oral Radiol Oral Endod. 2004;98(3):376-9.

8. Camilleri J, Peplow G, Schembri M. Analyses of heavy metals in mineral trioxide aggregate and Portland cement. J. Endod. 2010;36(7):1210-5. doi: 10.1016/j.joen.2010.02.011

9. Al-hezaini K, Salameh Z, Al-fouzan K, Al-rejaie M, Tay FR. Histomorphometric and micro-computed tomography analysys of pulpal response to three different pulp capping materials. J Endod. 2011;37(4):507-12. doi: 10.1016/j.joen.2010.11.001

10. Torabinejad $M$, Hong CU, Pitt Ford TR, Kattering JD. Antibacterial effects of some root and filling materials. J Endod 1995;21(8):403-6

11. Sipert CR, Husnne RP, Nishiyama CK, Torres SA. In vitro antimicrobial activity of Fill Canal, Sealapex, Mineral Trioxide Aggregate, Portland cement and EndoRez. Int Endod J. 2005;38(5):539-43
MTA and PC inhibited all tested microbial strains, except E. faecalis.

\section{Collaborators}

PMR MELO JR, APV SOBRAL and GC SAMPAIO participated in writing, revised the text and in the drafting of the article. MAP PINTO and NZS SHINOHARA were responsible for the interpretation of results.

12. Tanumaru-filho M, Tanumaru JMG, Barros DB; Watanabe E, Ito IY. In vitro antimicrobial activity of endodontic sealers, MTA-based cements and Portland cement. J Oral Sci. 2007;49(1):41-5.

13. Ribeiro CS, Kuteken FA, Hirata Jr R, Scelza MFZ. Avaliação comparativa da ação antimicrobiana do MTA, hidróxido de cálcio e cimento Portland. J Appl Oral Sci. 2006;14(5):330-5. doi: 10.1590/S1678-77572006000500006

14. Zarrabi $\mathbf{M H}$, Javidi $M$, Naderinasab $M$, Gharechahi $M$. Comparative evaluation of antimicrobial activity of three cements: new endodontic cement (NEC), mineral trioxide aggregate (MTA) and Portland. J Oral Sci. 2009;51(3):437-42.

15. Provenzano JC, Oliveira JCM, Alves FRF, Rôças IN, Siqueira Jr JF, Uzeda M. Antibacterial activity of root-end filling materials. Acta Stomatol Croat. 2011;45(1):3-7.

16. Gross EL, Leys EJ, Gasparovich SR, Firestone ND, Schwartzbaum JA, Janies, DA. Bacterial 16S sequence analysis of severe caries in young permanent teeth. J Clin Microbiol. 2010;48(11):4121-8. doi: 10.1128/JCM.01232-10

17. Nadkarni MA, Simonian MR, Harty DWS, Zoellner $H$, Jacques NA, Hunter N. Lactobacilli are proeminent in the initial satges of polymicrobial infection of dental pulp. J Clin Microbiology. 2010;48(5):1732-40. doi: 10.1128/JCM.01912-09

18. Huang T, Chen C, Hung C, Kao C. Comparison of antibacterial activities of root-end filling materials by an agar diffusion assay and Alamar blue assay. J Dent Sci. 2012;7(4):336-41. doi:10.1016/j.jds.2012.05.001

19. Da Silva LAB, Leonardo MR, Da Silva RS, Assed S, Guimarães LF Calcium hydroxide root canal sealers: evaluation of $\mathrm{pH}$, calcium íon concentration and conductivity. Int Endod J. 1997;30(3):4036.

20. Leonardo MR, Silva LAB, Tanomaru-Filho M, Bonifácio KC, Ito IY. In vitro evaluation of antimicrobial activity of sealers and pastes used in endodontics. J Endod. 2000;26(7):391-4. doi:10.1097/00004770-200007000-00003

21. Holland R, De Souza V, Murata SS. Healing, process of dog dental pulp after pulpotomy and covering with mineral trioxide agregate or Portland cement. Braz Dent J. 2001b;12(2):109-13.

22. Duarte MAH. Avaliação da contaminação do MTA Ângelus e do cimento de Portland. J Bras Clin Odontol Int. 2002;6(32):155-7.

23. Torabinejad $M$, Parirokh $M$. Mineral trioxide aggregate: a comprehensive literature review - Part I: chemical, physical, 
and antibacterial properties. J Endod, 2010;36(1):16-27. doi: 10.1016/j.joen.2009.09.006

24. Myagak DC, Carvalho EMOF, Robazza CRC, Chavasco JK, Levorato GL. In vitro evaluation of the antimicrobial activity of endodontic sealers. Braz Oral Res. 2006;20(4):303-6. doi: 10.1590/S1806-83242006000400004

25. Islam I, Chng HK, lap AU. Comparison of the physical and mechanical properties of MTA and Portland cements. J Endod. 2006;32(3):193-7. doi:10.1016/j.joen.2005.10.043
26. Vasconcelos BC, Bernardes RA, Cruz SM, Duarte MA, Padilha PDM, Bernardineli $\mathrm{N}$. Evaluation of $\mathrm{pH}$ and calcium ín release of new root-end filling materials. Oral Surg Oral Med Oral Pathol Oral Radiol Oral Endod. 2009;108(1):135-9. doi:10.1016/j. tripleo.2009.02.026

Received on: 10/5/2013 Final version resubmitted on: 16/2/2014 Approved on: 16/10/2014 
